\title{
Experimental Study of New Collagen-containing Preparations
}

\author{
Olga Andreyeva ${ }^{1}$ and Lesia Maistrenko ${ }^{1^{*}}$ \\ ${ }^{1}$ Kyiv National University of Technologies and Design, Ukraine.
}

\begin{abstract}
Authors' contributions:
This work was carried out in collaboration between all authors. Author OA designed the study, wrote the protocol, and wrote the first draft of the manuscript. Author LM performed the statistical analysis, managed the analyses of the study and the literature searches. All authors read and approved the final manuscript.

Article Information

DOI: 10.9734/ACSJ/2015/20468 Editor(s):

$(1)$.

Reviewers:

(1).

(2).

(3).

Complete Peer review History:
\end{abstract}

\section{ABSTRACT}

Leather industry is one of the main sources of collagen-containing raw materials. Therefore, effective recycling of these raw materials into marketable products is a pressing problem not only for leather industry but also for other branches of national economy. In the present work, we have studied into new collagen-containing preparations, derived from untanned by-products of leather industry. The size of particles in collagen preparations was assessed using microscopy. Chemical analysis was carried out under chemical research technique. IR spectroscopy has revealed the presence of various functional groups in the structure of developed preparations. Based on the results of experimental data, we concluded that new collagen-containing preparations can be used in many sectors of national economy.

Keywords: Collagen; leather wastes; IR-spectroscopy; properties. 


\section{REFERENCES}

1. Robinson, C. Nature and structure of collagen. London: Butterworths;1953.

2. Zhuravsky V.A., Kasian E.E., Danylkovych A.G. Leather and fur technology. Kyiv: DALPU; 1996. Ukrainian.

3. Pustylnik Ya.l. Tanning wastes - goldmine. In the world of equipments. 2002; 2 (19): 44-48. Russian.

4. Fedorova M., Zenkov A. Addressing problems of ecology in factory "Russian leather". Leather and footwear. 2004; 2 (14): 42-45. Russian.

5. Zhuravsky V.A. Low-waste technology of the leather industry. Moscow: Legprombytizdat; 1993. Russian.

6. Karpukhina L.I., Ponomarev A.V., Tchaikovsky R.I. Recycling of wastes of leather and footwear production. Kiev: Technology; 1983. Russian.

7. Zainescu G.A., Mihalache M., Voicu P., Constantinescu R., Ilie L., Obrisca M. Biopolymers systems from leather wastes for degraded soils remediation. Scientific Papers, UASVM Bucharest. 2011; LIV:6068.

8. Hua Yang, Zibin Shu. The extraction of collagen protein from pigskin, $J$ Chem Pharm Res, 2014;6(2):683-687

9. Brown EM, Taylor MM, Marner WN. Production and potential uses of coproducts from solid tannery waste. J Am Leather Chem Assoc. 1996;91:270-275.

10. Casparus J., Reinhard V., editors. Products and application of biopolymers. Croatia: InTeh; 2012.
11. Andreyeva O. A., Maistrenko L. A., Tegza M. M. The usage of materials polyfunctionality in modern low-waste technologies. In: Materials of the III International research and practice conference «International Conference on European Science and Technology». Munich: Publishing office Vela Velard Waldkraiburg 2012; Vol. I:107-111.

12. Tehza M.M., Andreeva O.A. Investigation of collagen preparations. Bulletin of the KNU. 2011; 4: 128-132. Ukrainian.

13. Danilkovich A.G., Chursin V.I. Workshop on chemistry and technology of leather and fur. Moscow: TSNIIKP; 2002. Russian.

14. Leather. Test methods. Moscow: Publishing House of Standards, 1988. Russian

15. Zhebentyaev A.I., Zharnasiek A.K., Talut I.E. Analytical chemistry. Chemical methods of analysis. Minsk: New knowledge; 2010. Russian.

16. Stuart B., editor D. J. Ando, Biological application of infrared spectroscopy: University of Grinwich; 1997.

17. Liu Jie, Li Xiaoyu, Wang Wei, Xiao Wu, Zhang Jun, Zhou Zhu. Measurement of protein content in chestnuts using near infrared spectroscopy. J Chem Pharm Res. 2014; 6(6):938-941.

18. Sarver RW, Krueger WC. Protein secondary structure from fourier transform infrared spectroscopy: A data base analysis. Anal Biochem. 1991;194:89-100.

19. Maistrenko L.A., Andreyeva O.A. IRspectroscopic studies of polymeric compounds of the new generation. Message 1. Bulletin of the KNTU. 2011; 4: 143-147. Ukrainian. 